\title{
Structural and optical properties of CdS:Sn thin films prepared by chemical spray pyrolysis method
}

\author{
Nadia Jasim Ghdeeb \\ College of Science, University of Mustansiriya, Baghdad, Iraq \\ E-mail: nadiajasim127@yahoo.com
}

\begin{abstract}
CdS and CdS:Sn thin films were successfully deposited on glass substrates by spray pyrolysis method. The films were grown at substrate temperatures $300 \mathrm{C}^{\circ}$. The effects of Sn concentration on the structural and optical properties were studied.

The XRD profiles showed that the films are polycrystalline with hexagonal structure grown preferentially along the (002) axis. The optical studies exhibit direct allowed transition. Energy band gap vary from 3.2 to $2.7 \mathrm{eV}$.
\end{abstract}

Key words

CdS:Sn films, Spray pyrolysis, XRD and Optical properties.
Article info.

Received: Jun. 2015

Accepted: Feb. 2016

Published: Apr. 2016

\section{الخصائص التركيبية والبصرية لاغشية كبريتيد الكادميوم المشوبة بالقصدير المحضرة بطريقة

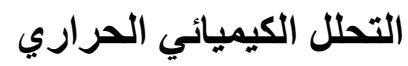

اغشية كبريتيد الكادميوم و كبريتيد الكادميوم المشوبة بالقصدير الرقيقة رسبت بنجاح على قواعد زجاجية

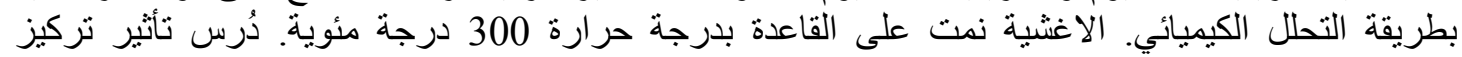
القصدير على الخصائص التركيبية والبية البصرية. بينت فحوصات الاشعة السينية ان الاغشية متعددة التبلور وذات التية تركيب سداسي و الاتجاه السائد ( 200). بينت در اسة الخصائص البصرية ان الانتقال مبانر مسموح وفجوة الطاقة تتغير من 3.2 الى 2.7 الكترون فولت التهاه

\section{Introduction}

Cadmium sulphide (CdS) is a II-VI binary semiconductor material, its actual color is yellow [1] having two crystal structure, cubic and hexagonal phases [2]. CdS is insoluble in water but soluble in acids [3]. It has direct energy gab equal to $2.42 \mathrm{eV}$ at $(300 \mathrm{~K})$ so that the blue region of the spectrum is absorbed by the crystal. The intrinsic conductivity of $\mathrm{CdS}$ material at room temperature is low because of the high value of its energy gap compared with Silicon $1.12 \mathrm{eV}$ and Germanium $0.66 \mathrm{eV}[4,5] . \mathrm{CdS}$ is an important material due to its novel properties like high photoconductivity, high index of refraction (2.5) and its high electron affinity [6]. Besides it is one of the most promising materials for application in electronic and optoelectronic devices such as solar cell, photo sensors, laser materials, optical filters, multilayer light emitting, thin film field effect transistors and gas sensors [7,8]. Polycrystalline CdS films are generally used in CdTe, CuInSe 2 (CIS) and $\mathrm{CuInGaSe}_{2}$ (CIGS) solar cell as a window material for transmitting the 
light absorbed by CdTe, (CIS) or (CIGS), also as the n-type material for p-n junction of solar cells $[6,7]$.

Cadmium sulfide (CdS) thin film has attracted increased attention in recent years because of its wide direct band gap energy, optical and electrical properties, and stability, which is suitable for application as a window layer in solar cells [9]. Various methods employed for deposition CdS film, such as chemical vapour deposition, sputtering and spray pyrolysis [10], chemical bath deposition (CBD) [11,12], close space sublimation (CSS), and successive ionic layer adsorption and reaction (SILAR) [13].

\section{Experimental}

$\mathrm{CdS}$ thin film were prepared by spray pyrolysis of aqueous solution of cadmium chloride $\left(\mathrm{CdCl}_{2} \cdot \mathrm{H}_{2} \mathrm{O}\right)$ and thiourea $\left(\mathrm{NH}_{2} \mathrm{CSNH}_{2}\right)$. The molar concentration of the solution should be equal to 0.1 mole/liter. In order to prepare the solution of 0.1 molar few grams, [(2.62935 gm) $\mathrm{SnCl}_{2} . \mathrm{H}_{2} \mathrm{O}$,

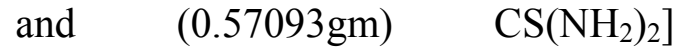
concentrations from these two material are weight needed from each of them, melted in 50 liter of distilled water, according to the following equation:

$\mathrm{M}=(\mathrm{Wt} / \mathrm{Mwt})$. $(1000 / \mathrm{V})$

Wt: Weight of the material (gm), $\mathrm{V}$ :Volum(L),M:Moleculaconcentration (M/L), Mwt: Molecular weight $(\mathrm{gm} / \mathrm{M})$. This composition was optimum to give higher optical transparency.

The substrate were heated to a temperature of about $300^{\circ} \mathrm{C}$ for $20 \mathrm{~min}$ before spraying in small amounts to avoid excessive cooling of hot substrate during spraying. To obtain films of uniform thickness the distance between sprayer and substrate was kept $30 \pm 1 \mathrm{~cm}$.
To prepared CdS:doped with tin $\mathrm{Sn}$, we added tin chloride $\left(\mathrm{SnCl}_{2} \cdot 2 \mathrm{H}_{2} \mathrm{O}\right)$ $(1,2,3 \mathrm{wt} \%)$ to $\left(\mathrm{CdCl}_{2} \cdot \mathrm{H}_{2} \mathrm{O}\right)$ and $\left(\mathrm{NH}_{2} \mathrm{CSNH}_{2}\right)$ solution.

$\mathrm{CdS}$ and CdS:Sn films were prepared on glass substrat. The coating was found to be stable and has a very good adhesive properties.

The transmission and absorption spectra were obtained over the range (300-1100)nm by UV-VISIBLE recording spectrometer (Shimadzu model UV-160).

\section{Result and discussion}

\section{Structural properties}

The X-ray diffraction patterns of $\mathrm{CdS}$ and $\mathrm{CdS}: \mathrm{Sn}$ thin film grown on glass substrates were prepared by chemical spray pyrolysis method where Sn constration equal to $(1,2$, $3) \%$ are shown in Fig. 1 respectively. The thickness of the films have been measured to be $(200 \pm 4) \mathrm{nm}$. All XRD patterns reveal polycrystalline nature of prepared samples. Table 1 illustrates bragg's angles, inter planers spacing, and miller indices of CdS and CdS:Sn thin film.

From Fig.1a where $(\mathrm{S} n=0)$ corresponding to $\mathrm{CdS}$ thin film, it can be observed that the dominant phase was hexagonal with preferential orientation along (002) at $26.5045^{\circ}$. Also it can be observed an existing of two peaks along (100) and (101) at 24.822, 28.1794, as matched with the ASTM (American Standards for Testing Materials) card of CdS. This is attributed to the nature of chalcogenides of cadmium which normally show the duality in their crystal structure which means that they can be formed with either sphalerite (cubic, zinc blend type) or wurtzite (hexagonal type) [4] or mixed structures [6]. Our results are agree with A. Ashour [14] who found that $\mathrm{CdS}$ thin film of hexagonal phases with preferential orientation along 
(002). From Fig.1b where $(\mathrm{Sn}=1)$ it can be observed of CdS:Sn crystals with hexagonal structure with preferential orientation along (002) at $26.82^{\circ}$ for $\mathrm{CdS}$ and the dominant orientation for CdS:Sn crystals was along (100), (101) at 24.8654, $28.2228^{\circ}$ respectively. From Fig. 1c where $(\mathrm{Sn}=2)$ it can be also observed a of CdS:Sn crystals with hexagonal structure and the dominant orientation for CdS crystals was along (002),
(100) and (101) at 26.5658, 24.9698, 28.1958. Finally, from Fig. 1d where $(\mathrm{Sn}=3)$ corresponding to $\mathrm{CdS}: \mathrm{Sn}$ thin film, it is clear that the pure hexagonal structure was dominated for all peaks as matched with the ASTM card of $\mathrm{CdS}$ with preferential orientation along (002) at $26.1900^{\circ}$. From Figure Ncesph note that an increase of the Sn less than intensity while has higher intensity of $\mathrm{CdS}$ and this explains.

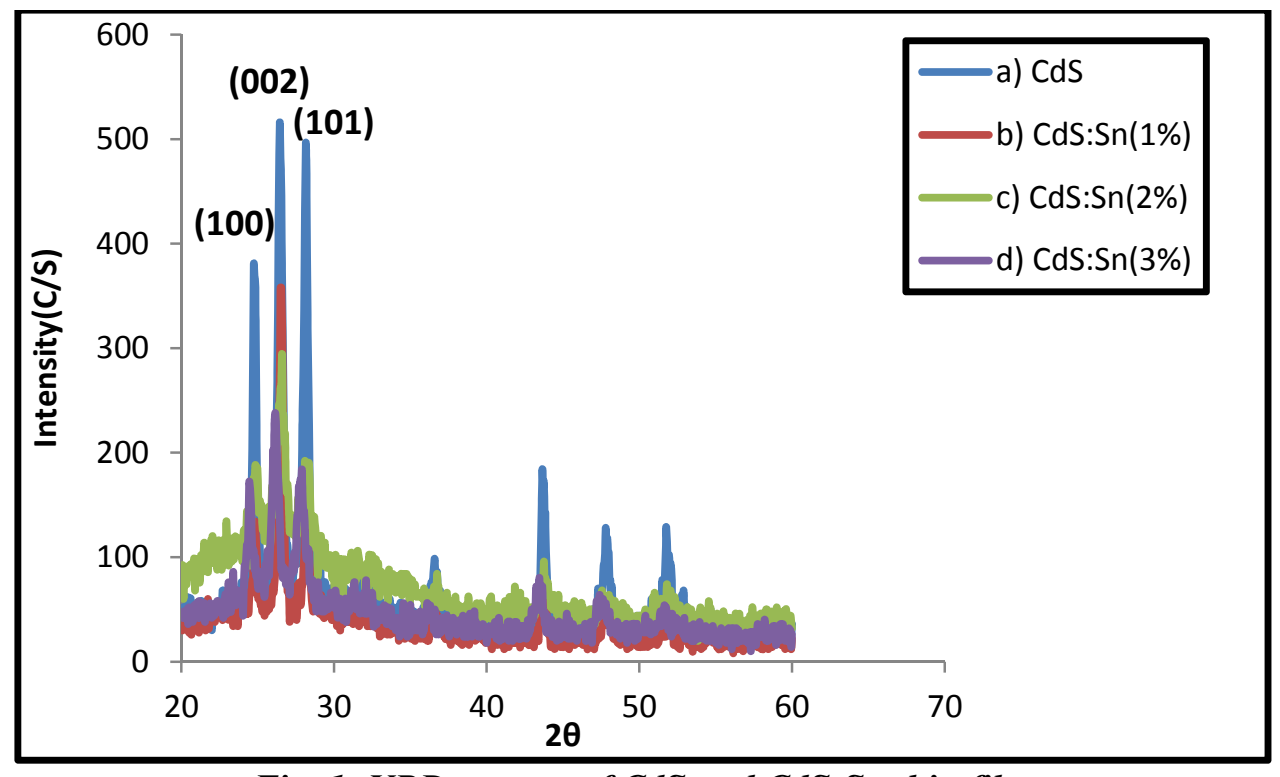

Fig. 1: XRD pattern of CdS and CdS:Sn thin film.

Table 1: The strucural parameters of CdS:Sn thin film.

\begin{tabular}{|c|c|c|c|c|c|}
\hline Film & $2 \theta_{\text {Exp }}$.(deg) & $2 \theta_{\text {Stan .(deg) }}$ & $d_{\operatorname{Exp}} .\left(A^{0}\right)$ & $\mathrm{d}_{\text {Stan. }}\left(\mathrm{A}^{0}\right)$ & (hkl) \\
\hline $\mathrm{CdS}$ & $\begin{array}{l}24.8228 \\
26.5045 \\
28.1794\end{array}$ & $\begin{array}{l}24.807 \\
26.507 \\
28.182\end{array}$ & $\begin{array}{l}3.58396 \\
3.36025 \\
3.16417\end{array}$ & $\begin{array}{l}3.5861 \\
3.3599 \\
3.1638\end{array}$ & $\begin{array}{l}100 \\
002 \\
101\end{array}$ \\
\hline $\mathrm{CdS}: \operatorname{Sn}(1 \%)$ & $\begin{array}{l}24.8654 \\
26.5642 \\
28.2228\end{array}$ & $\begin{array}{l}24.807 \\
26.507 \\
28.182\end{array}$ & $\begin{array}{l}3.57792 \\
3.35284 \\
3.15945\end{array}$ & $\begin{array}{l}3.5861 \\
3.3599 \\
3.1638\end{array}$ & $\begin{array}{l}100 \\
002 \\
101\end{array}$ \\
\hline CdS:Sn(2\%) & $\begin{array}{l}24.9698 \\
26.5658 \\
28.1958\end{array}$ & $\begin{array}{l}24.807 \\
26.507 \\
28.182\end{array}$ & $\begin{array}{l}3.56320 \\
3.35264 \\
3.16242\end{array}$ & $\begin{array}{l}3.5861 \\
3.3599 \\
3.1638\end{array}$ & $\begin{array}{l}100 \\
002 \\
101\end{array}$ \\
\hline CdS:Sn(3\%) & $\begin{array}{l}24.5310 \\
26.1900 \\
27.8570\end{array}$ & $\begin{array}{l}24.807 \\
26.507 \\
28.182\end{array}$ & $\begin{array}{l}3.62593 \\
3.39989 \\
3.20010\end{array}$ & $\begin{array}{l}3.5861 \\
3.3599 \\
3.1638\end{array}$ & $\begin{array}{l}100 \\
002 \\
101\end{array}$ \\
\hline
\end{tabular}


as well as indicates that the lattice constants decrease with the increasing in $\mathrm{Sn}$ concentration as listed in Table 2 and calculated from the following equation [15]:

$\frac{1}{d^{2}}=\frac{4}{3}\left[\frac{h^{2}+h k+k^{2}}{a^{2}}\right]+\frac{l^{2}}{c^{2}}$

where $d:$ is the interplaner distance.

$h k l$ : miller indices.

$a, c$ : lattice constants.

The calculated values of lattice constants for $\mathrm{CdS}$ and $\mathrm{CdS}: \mathrm{Sn}$ thin films are in good agreement with ASTM data.

It is clear from XRD patterns of CdS and CdS:Sn thin films, that the full width at half maximum (FWHM) increases with the increasing of $\mathrm{Sn}$ concentration in these films. This decreasing in (FWHM) indicates an fluctuating in the grain size of $\mathrm{CdS}$ and CdS:Sn thin films as given in Table 2 according to Scherrer's formula where the relation between the grain size (D) and (FWHM) is reversal as follows [16]:

$\mathrm{D}=\frac{0.9 \lambda}{\beta \cos \theta}$

where $\beta$ : is the full width at half maximum (FWHM) in radian and $\lambda$ : is the X-ray wavelength $\left(1.5406 \mathrm{~A}^{\mathrm{o}}\right)$.

The dislocation density $(\delta)$ of $\mathrm{CdS}$ and CdS:Sn thin films which defined as the length of dislocation lines per unit volume of the crystal was calculated from this equation [17]:

$\delta=\frac{1}{\mathrm{D}^{2}}$

The values of the dislocation density of $\mathrm{CdS}$ and $\mathrm{CdS}: \mathrm{Sn}$ thin films are given in Table 2. It is evident from this table that the dislocation density of $\mathrm{CdS}$ and CdS:Sn thin films increases with increasing in $\mathrm{Sn}$ concentration which can be also deduced from the increasing in the grain size where the dislocation density is proportion reversely with the square of the grain size according to Eq.(4). The strain $(\xi)$ developed in CdS and CdS:Sn thin films can calculated from the relation[18]:

$\xi=\frac{\beta \cos \theta}{4}$

The values of the strain of CdS and $\mathrm{CdS}: \mathrm{Sn}$ thin films are given in Table 2. It is clear from this table that the strain in $\mathrm{CdS}$ and $\mathrm{CdS}: \mathrm{Sn}$ thin films increases with increasing in $\mathrm{Sn}$ concentration which can be also deduced from the decreasing in the grain size, where the increasing in the strain and the dislocation density with the decreasing in the grain size is a well-known phenomenon [19].

Table 2: Variation of the full width at half maximum, grain size, lattice constants, dislocation density and strain of CdS and CdS:Sn thin film.

\begin{tabular}{|c|c|c|c|c|c|c|}
\hline \multirow{2}{*}{ Film } & \multirow{2}{*}{$\begin{array}{c}\text { (FWHM) } \\
\text { rad }\end{array}$} & \multirow{2}{*}{$\begin{array}{c}\text { Grain size } \\
(\mathrm{nm})\end{array}$} & \multicolumn{2}{|c|}{ Lattice Constants } & \multirow{2}{*}{$\begin{array}{l}\text { Dislocation density } \\
\left(\text { lines. } \AA^{-2}\right) \times 10^{-5}\end{array}$} & \multirow{2}{*}{ Strain (rad) $\times 10^{-3}$} \\
\hline & & & $\mathbf{a}(\AA)$ & $\mathbf{c}(\AA)$ & & \\
\hline $\mathrm{CdS}$ & 0.00603229 & 237.005013 & 4.69534 & 6.32834 & 1.780266 & 1.46254 \\
\hline CdS:Sn(1\%) & 0.006274 & 227.8301 & 4.6859 & 6.3189 & 1.9265 & 1.52146 \\
\hline $\mathrm{CdS}: \operatorname{Sn}(2 \%)$ & 0.010839985 & 131.788 & 5.5934 & 7.1264 & 5.7576426 & 2.630293 \\
\hline CdS:Sn(3\%) & 0.015176 & 106.7648 & 4.7672 & 6.4002 & 8.7729 & 3.2467 \\
\hline
\end{tabular}




\section{Optical properties}

The transmittance spectrum of $\mathrm{CdS}$ and CdS:Sn thin films where Sn equal $(1,2,3) \%$ are shown in Fig. 2. It is clear from this figure that the transmittance increases with increasing in Sn concentration which can be also deduced from the changing in the films' colure, from yellowish color for $\mathrm{x}=0$ (CdS thin film) to dark yellowish for (CdS:Sn thin film). The absorbance spectrums of CdS:Sn thin films where $\mathrm{Sn}$ equal $(1,2,3) \%$ are shown in Fig. 3. It is clear that as the $\mathrm{Sn}$ concentration increases the absorbance of $\mathrm{CdS}: \mathrm{Sn}$ thin films is decreased.

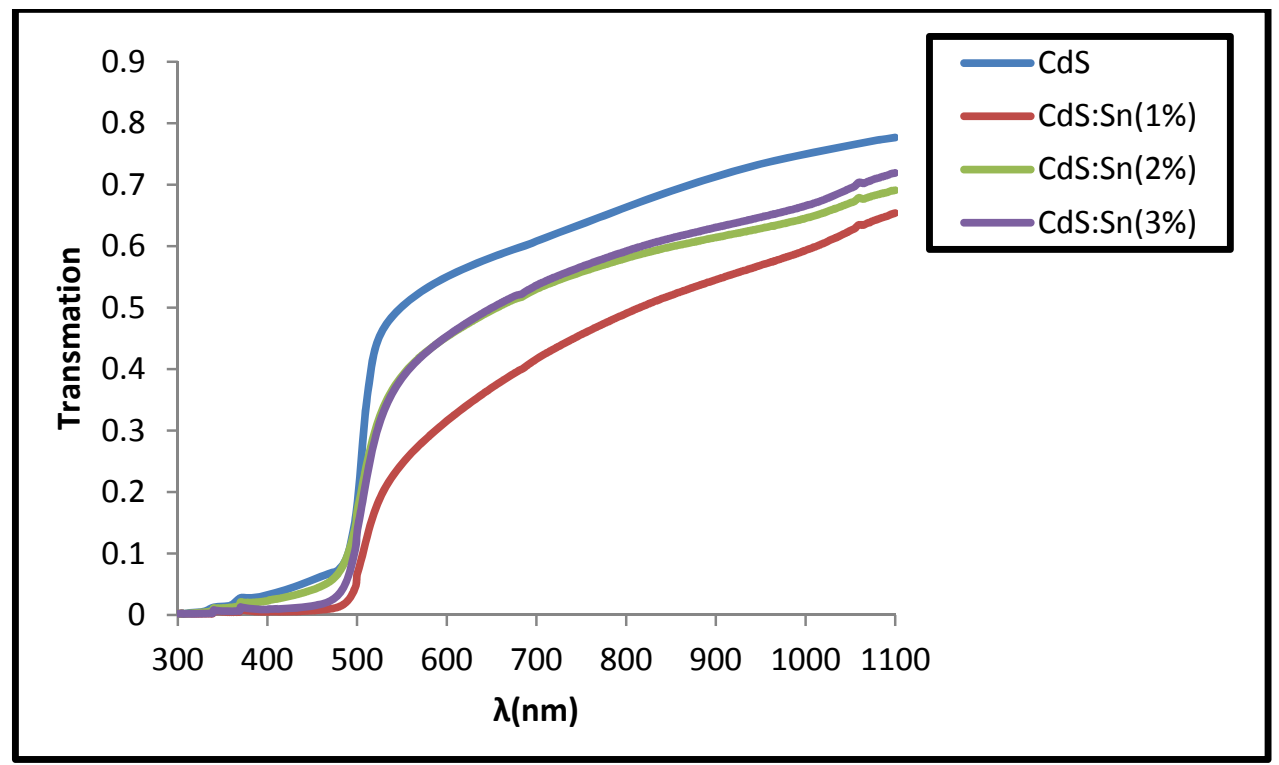

Fig. 2: Transmission spectrum of CdS and CdS:Sn thin film.

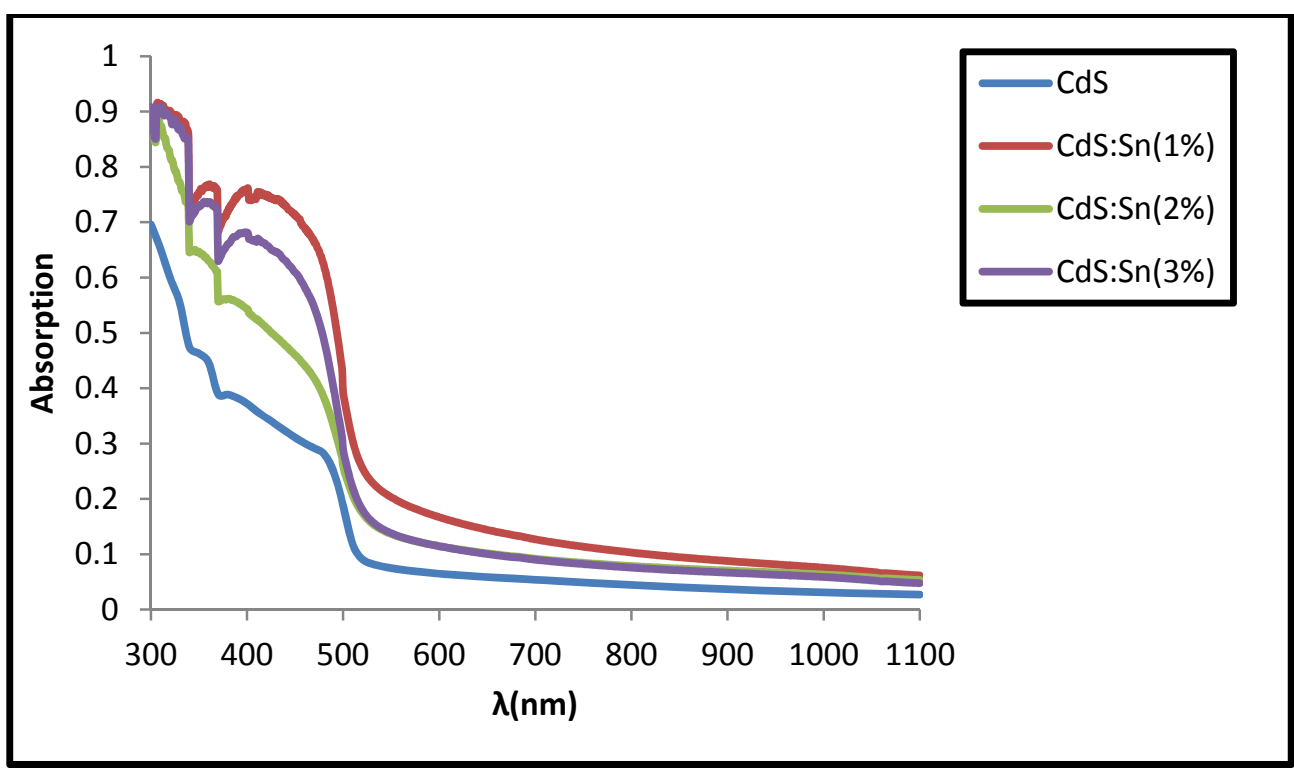

Fig. 3: Absorbance spectrums of CdS and CdS:Sn thin film. 
The absorption coefficient $(\alpha)$ of CdS and CdS:Sn thin films, was determined by using Eq.(6).

$$
\alpha=2.303 \frac{\mathrm{A}}{\mathrm{t}}
$$

The variation of the absorption coefficient of $\mathrm{CdS}$ and $\mathrm{CdS}: \mathrm{Sn}$ thin films with the wavelength for $\mathrm{Sn}$ constretion equal to $(0,1,2$ and 3$) \%$ is shown in Fig. 4. It can be noticed that the value of the absorption coefficient of CdS and CdS:Sn thin films is of the order of $\left(10^{4}\right) \mathrm{cm}^{-1}$ which supports the direct band gap nature of the semiconductor [20]. Our result agrees with Yadav and Masumdar [21] and also agree with Muthukumaran and Muthusamy [22]. It is also clear that the absorption coefficient of CdS and CdS:Sn thin films decreases with the increase in $\mathrm{Sn}$ concentration. This is attributed to the decrease in the absorbance of $\mathrm{CdS}$ and $\mathrm{CdS}: \mathrm{Sn}$ thin films with the increase in $\mathrm{Sn}$ concentration causing an increment in their absorption coefficient where the relation between the absorbance and absorption coefficient is proportional at constant thickness according to Eq.(6).

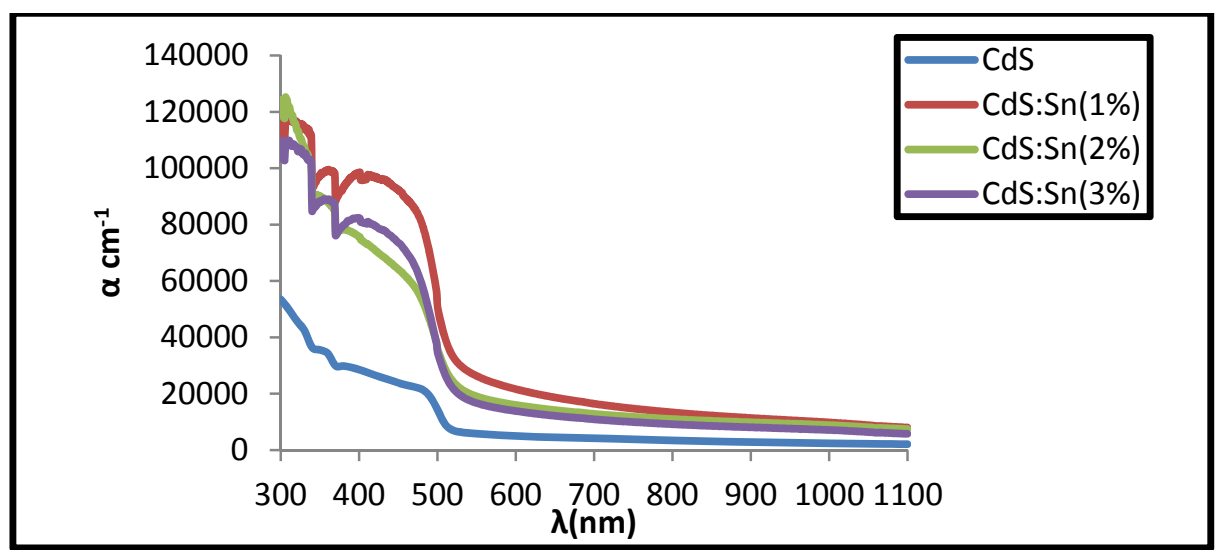

Fig. 4: Absorption coefficient of CdS and CdS:Sn thin film.

The optical energy gap values $\left(E_{g}\right)$ for CdS:Sn thin films prepared by chemical spray pyrolysis methode have been determined from the region of the high absorption at the fundamental absorption edge of these films by using Tauc equation [23]:

$\alpha h v=B_{o}\left(h v-E_{g}\right)^{r}$

where hu: is the incident photon energy in $\mathrm{eV}, \mathrm{B}_{\mathrm{o}}$ : is a constant depends on the nature of the material (properties of its valence and conduction band) [39] and $r$ : is a constant depends on the nature of the transition between the top of the valence band and bottom of the conduction band.

This equation is used to find the type of the optical transition by plotting the relations $(\alpha h v)^{2},(\alpha h v)^{1 / 2},(\alpha h v)^{2 / 3}$ and $(\alpha h v)^{1 / 3}$ versus photon energy (hv) and select the optimum linear part. It is found that the first relation yields linear dependence, which describes the allowed direct transition, then $\mathrm{E}_{\mathrm{g}}$ was determined by the extrapolation of the portion at ( $\alpha=0)$ as shown in Fig. 5. It is clear that the optical energy gap for $\mathrm{CdS}$ and CdS:Sn thin films decreases as the Sn concentration in the films increased. The optical energy gap values for $\mathrm{CdS}$ and $\mathrm{CdS}: \mathrm{Sn}$ thin films were $3.2 \mathrm{eV}, 2.9 \mathrm{eV}, 2.8 \mathrm{eV}$ and 2.7 $\mathrm{eV}$ for $\mathrm{Sn}$ concentration $(0,1,2$ and 3$)$ respectively. Fig. 5 illustrates the variation of the optical energy gap for $\mathrm{CdS}$ and CdS:Sn thin films with concentration (Sn). 

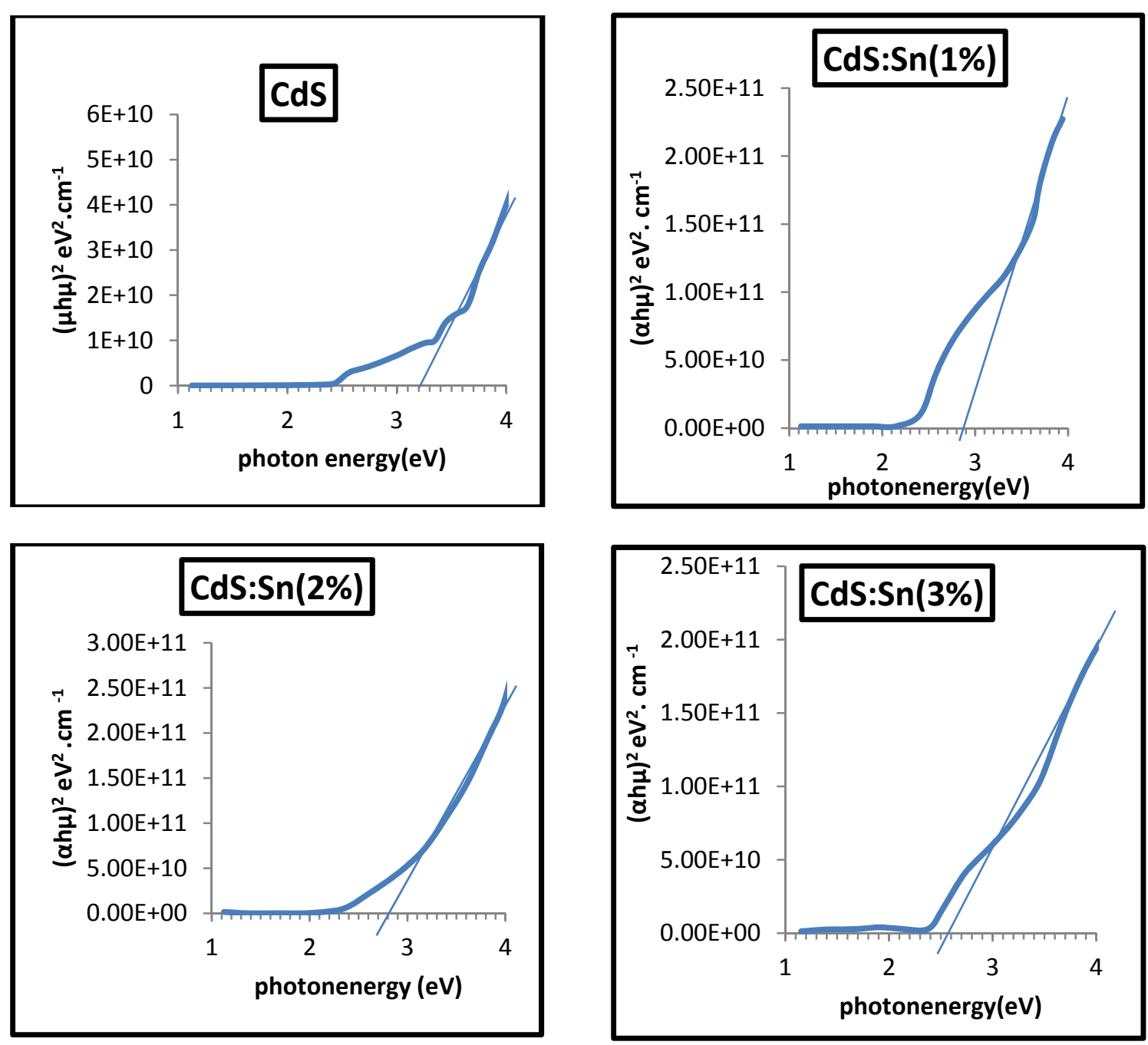

Fig. 5: $(\alpha h v)^{2}$ as a function of hv for CdS and CdS:Sn thin film.

The refractive index $\left(n_{0}\right)$ of $\mathrm{CdS}$ and CdS:Sn thin films have been determined by using the following equation [24]:

$n_{\circ}=\sqrt{\frac{4 \mathrm{R}}{(\mathrm{R}-1)^{2}}-k_{\circ}^{2}}-\left(\frac{\mathrm{R}+1}{\mathrm{R}-1}\right)$

where R: is the reflectance of the films and $\mathrm{k}_{\mathrm{o}}$ : is the extinction coefficient.

The variation of the refractive index as a function of the wavelength for $\mathrm{CdS}$ $\mathrm{CdS}: \mathrm{Sn}$, thin films is illustrated in Fig.6. It is clear from this figure that the refractive index decreases with the increasing in the wavelength of the incident photon. Also it can be observed, that the refractive index of $\mathrm{CdS}$ and CdS:Sn thin films decreases with the increasing in the Sn concentration. This decreasing is attributed to the decreasing in the grain size of the films with the increasing in the Sn concentration which interns causing an increment in the compactness of the films which in turns reduces the speed of light in the material of the thin film and then leads to an increasing in the refractive index. Where $\left(n_{0}\right)$ varies according to the grain size even if the crystalline structure is itself of the material. 


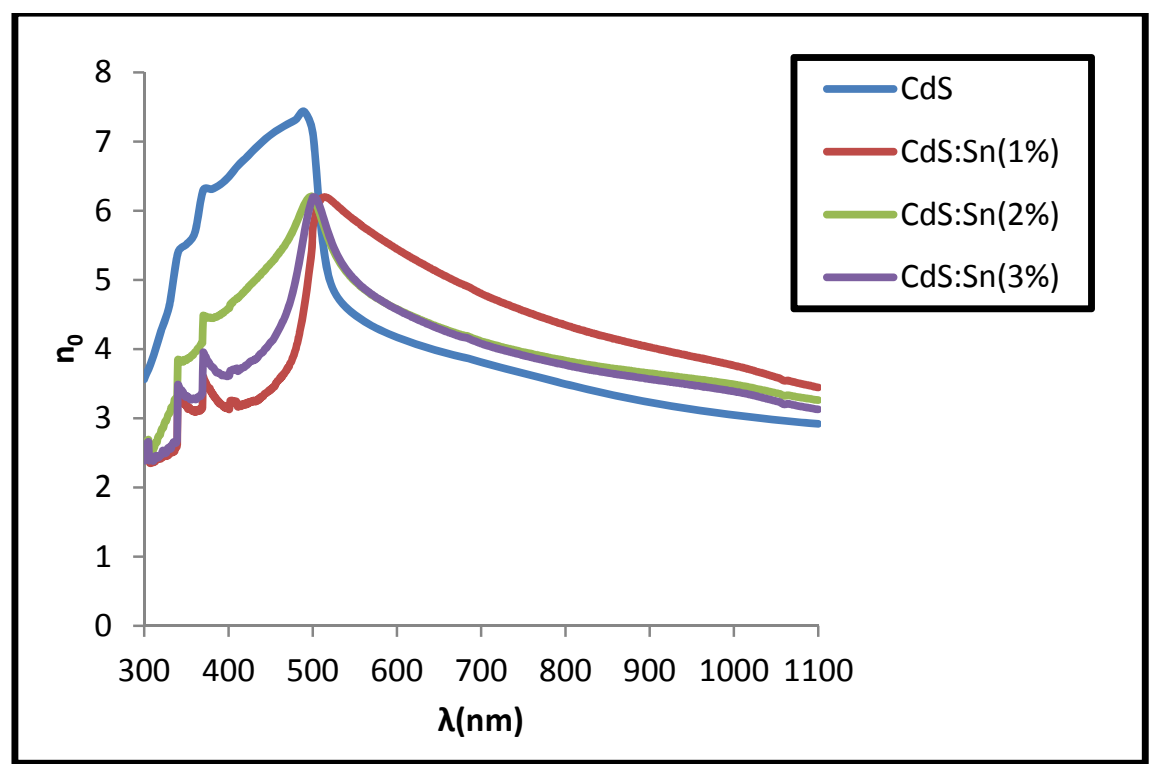

Fig. 6: The variation of the refractive index as a function of the wavelength for CdS and CdS:Sn thin film.

The extinction coefficient $(\mathrm{k} \circ)$ have been determined by using the following equation [24]:

$$
k_{\circ}=\frac{\alpha \lambda}{4 \pi}
$$

where $\lambda$ : is the wavelength of the incident photon.

It is clear from this equation that $\mathrm{k}$ 。 depends on $\alpha$ and has a similar behavior to $\alpha$. Fig. 7 illustrates the variation of the extinction coefficient of CdS and CdS:Sn thin films with the wavelength, with the increasing in the $\mathrm{Sn}$ concentration the extinction coefficient $\mathrm{k}$ o increases. This is attributed to the increasing in the absorption coefficient due to the increasing of the depth of donor levels associated with sulfur vacancies and these levels will be available for the photons to be absorbed causing an increment in the absorbance and leads to increase in the absorption coefficient. Therefore $\mathrm{k}$ 。 will increase with the increasing in the Sn concentration since it has a similar behavior to $\alpha$ and depends on it.

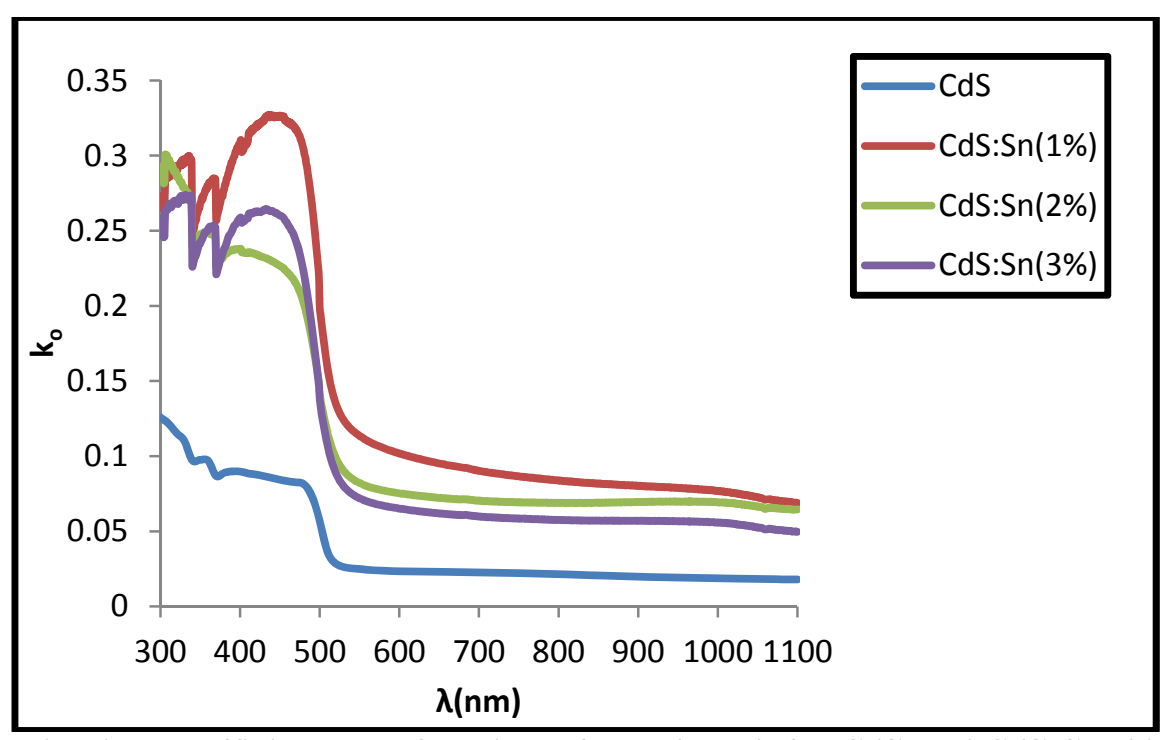

Fig. 7: Extinction coefficient as a function of wavelength for CdS and CdS:Sn thin film. 


\section{Conclusions}

$\mathrm{CdS}$ and CdS:Sn thin film thin films were successfully deposited using spray pyrolysis method at substrate temperatures $300{ }^{\circ} \mathrm{C}$. The crystalline and hexagonal $\mathrm{CdS}$ and $\mathrm{CdS}: \mathrm{Sn}$ thin films with only (002). Optical studied indicates that $\mathrm{CdS}$ and $\mathrm{CdS}: \mathrm{Sn}$ thin films exhibit direct band gap and band gap energy decreases with increase in $\mathrm{Sn}$ concentration. The variation of band gap energies from 3.2 to $2.7 \mathrm{eV}$.

\section{References}

[1] H. Joseph Simmons and S. Kelly Potter, "Optical materials", Academic Press, USA (2000).

[2] Sze, S. M., "Physics of Semiconductor Devices", John Wily \& Sons, New York, (1986).

[3] David R. Lide, "CRC Handbook of Chemistry and Physics", Taylor \& Francis Group LLC, (2006).

[4] R.Hill, "Active and passive thin film devices", Academic press, New York, (1978).

[5] Manal, J. K., "White light generation from the nanocrystalline cadmium sulfide illuminated by UV source", M. Sc. thesis, University of Baghdad, College of Science, (2010).

[6] Zahid Rizwan, Azmi Zakaria, Mohd Sabri, Mohd Ghazali, Atefeh Jafari, Fasih Ud Din, Reza Zamiri, Int. J. Mol. Sci, 12 (2011) 1293-1305.

[7] H. Metin, M. Ari, S. Erat, A. Braun, S. Durmus, M. Bozoklu, J. Mater. Res., 25, 1, January (2010) 189-196.

[8] S.Prabahar, N. Suryanarayanan, K. Rajasekar, S.Srikanth, D. Kathirvel, Chalcogenide Letters, 6, 7, June (2009) 309-313.

[9] Atefeh Jafari, Azmi Zakaria, Zahid Rizwan, Mohd Sabri Mohd Ghazali, Int. J. Mol. Sci. 12 (2011) 6320-6328. [10] A. Punnoose, M. Marafi, G. Prabu, F. Elakkad, Phys. States Solid, 177 (2000) 453-458.

[11] M.F. Bertino, R.R. Gadipalli, J.G. Story, C.G.Williams, G. Zhang, C.
Sotiriou-Leventis, A.T. Tokuhiro, S.Guha, N. Leventis, Appl. Phys. Lett., 85 (2004) 6007-6009.

[12] Q. Liu, G. Mao, Surf. Rev. Lett., 16 (2009) 469-474.

[13] K.M. Garadkar, A.A. Patil, P.V. Korake, P.P. Hankare, Arch. Appl. Sci. Res., 2 (2010) 429-437.

[14] A. Ashour, Journal of Optoelectronics and Advanced Materials, 8, 4, August (2006) 14471451.

[15] K. Sivaramamoorthy, S. Asath Bahadur, M. Kottaisamy, K. R. Murali, Crystal Research and Technology, 45, Issue 4, April (2010) 414-420.

[16] Y. Sitrotin and M. Shaskolskaya, "Fundamental of crystal physics", (Mir publishers, Moscow, 1982).

[17] M.M.EL Nahass and A.M.A. EL Barry, Indian Journal of Pure \& Applied Physics, 45, May (2007) 465475.

[18] Z.R. Khan, M. Zulfequar, M.S. Khan, Chalcogenide Letters, 7, 6, June (2010) 431-438.

[19] N.J. Suthan Kissinger, J. Suthagar, B. Saravana Kumarc, T. Balasubramaniam, K.Perumal, ACTA Physica Polonica A, 118, 4 (2010) 623-628.

[20] B.Ray, "II-VI Compounds", $1^{\text {st }}$ Ed. Printed in Great Britain, (1969).

[21] A. A. Yadav, E.U. Masumdar, Journal of Alloys and Compounds, 505 (2010) 787-792.

[22] S. Muthukumaran, M. Muthusamy, J. of Mater. Sci., Mater. in Elec., 23, 14 February (2012) 16471656.

[23] Manal, J. K., "White light generation from the nanocrystalline cadmium sulfide illuminated by UV source", M.Sc. thesis, p.25, January (2010).

[24] Zahid Rizwan, Azmi Zakaria, Mohd Sabri, Mohd Ghazali, Atefeh Jafari, Fasih Ud Din and Reza Zamiri, Int . J. Mol. Sci, 12 (2011) 1293-1305. 